ADDIN, Volume 12, Number 2, Agustus 2018

\title{
MARRIAGE TREASURE OWNERSHIP \\ IN ARABIC AND NUSANTARA FIQH PERSPECTIVES
}

\section{Nur Khoirin YD}

UIN Walisongo Semarang, Central Java, Indonesia

\section{Abstract}

One of the problems that often arise after the divorce is the ownership of assets acquired during marriage, whether it belongs to the husband, wife, or both of them. According to the Compilation of Islamic Law or the figh of the results of ijtihad fuqaha Nusantara, the assets obtained in marriage, except those obtained through inheritance or grants from parents/family, are joint property of husband and wife (gono gini). One party may not use it except getting agreement from the otherparties. And if marriage breaks, either because of divorce or death, then it must be divided into two. In the books of Arabic Fiqh, there is no joint property because marriage does not cause a mixture of wealth. Nonetheless, in the books of figh provides the possession of wife $>$ s assets, such as dowry, livelihood, mut $>$ ah, iwadl and tirkah. If the provision of figh is carried out consistently, then when a divorce occurs, the husband must leave the house, because all the property has become the property of his wife through a way of life. But this is certainly not fair. Therefore the determination of the existence of joint property in marriage is a moderate opinion and a benefit.

Keywords: Ownership, Property, Marriage, Arabic Fiqh, Nusantara Fiqh. 


\section{A. Introduction}

The status of marital property ownership is an issue that still needs more in-depth study. There is confusion between the Arabic Fiqh ${ }^{1}$ and Nusantara Fiqh ${ }^{2}$ about it. The Compilation of Islamic Law or Kompilasi Hukum Islam (KHI) as typical Nusantara Fiqh, and in Indonesian marriage law regulate the position of marital property. One manifestation of the principle of husband and wife balance in marriage adopted by Indonesian marriage law (Article 31 of Law1/1974, Article $79 \mathrm{KHI}$ ), the assets acquired during marriage become joint property. People often call it gono-gini property. The husband or wife cannot use it except with the consent of other parties (Articles 35 and 36 of Law-1/1974, Article 85 to $97 \mathrm{KHI}$ ). If the marriage is broken because of divorce, then the joint property must be divided become two; half for widow and half for widower. If the marriage is broken because of husband/wife death, the joint property must also be divided into two, as lousy as the surviving spouse, and half as an inheritance which must be shared with the rightful heirs (Articles 96-97 KHI).

Determination of the existence of joint assets in marriage is a new thing in the perspective of Arabic fiqh because the term of joint property is not known in the books of fiqh, or at least it is not clearly regulated. The books of munakahat figh throughout the discussion of property related

${ }^{1}$ Arabic Fiqh is just the author's own term to refer to the books of Fiqh using Arabic language compiled by the authors, most of whom are Arabs and with Arab social cultural settings. People also often call it Kitab Kuning.

${ }^{2}$ Nusantara Figh is a term to refer to Islamic Law which has been processed in such a way by Indonesian jurists, so that it has a distinctive Indonesian character which is different from Arabic fiqh. Nusantara's marriage jurisprudence is in the form of laws and regulations concerning marriage prevailing in Indonesia, including Law Number 1 of 1974 concerning Marriage, Government Regulation Number 9 of 1975 concerning Implementation, Presidential Instruction Number 1 of 1991 concerning Compilation of Islamic Law (Book I) and other applicable regulations. 
to marriage just have terms such as dowry, livelihood, mut'ah, iwadl and tirkah. Dowry or mahar is a compulsory gift in the form of something of value (property) from the husband to his wife and becomes the property of the wife and does not belong to his guardian as the case in the tradition before Islam. ${ }^{3}$ As a result of a legal marriage, one of the obligations of the husband towards his wife is to provide some things in the form of food, clothing and shelter according to a reasonable size. When marriage breaks because of divorce, the husband is recommended or obliged to give mut'ah, namely the giving of a kind of memento in the form of property to his ex-wife. Whereas if marriage breaks because one dies, then each can inherit the property left behind (tirkah).

From the lack of clarity about the status of marital property according to the Arabic fiqh and the difference in views between figh and the law, it is necessary to conduct methodological studies. Through this critical study, it is expected that there will be mutual correction and complementarity, so that between Arabic figh and Nusantara figh is no longer felt as two concepts that face each other, but goes hand in hand. This paper will discuss assets related to marriage and ownership law through special studies and their distribution if marriage breaks.

\section{B. Discussion}

\section{Ownership of Marriage Assets in Arabic Fiqh}

In the books of Arabic fiqh, there is no special discussion of marriage property as intended by the Indonesian Nusantara Fiqh. The discussion of marital property in fiqh will be seen in the context of dowry,

${ }^{3}$ Ibnu Mas'ud Al Kasany Al Hanafi, Bada'I al Shana'iy, Juz IV, (Bairut Libanon : Dar al Kutub Al Ilmiyah, tt.), pp. 15; See, Ibnu Rusyd Al Quthuby, Bidayah al Mujtabid, Juz 2 (Bairut: Dar al Fikr, tt.), pp. 39 
the obligation of livelihood for the husband, wages for breastfeeding, mut'ah, iwadl and tirkah. Therefore, this section will discuss these matters in the context of their ownership. This study is intended to find out which assets belong to the wife and which belong to the husband. The discussion about 'whether marriage causes a mixture of assets or not' is also need to be done.

\section{a. Mixing Treasure}

In principle, the marriage contract does not cause the mixing of the husband and wife property that they obtained before marriage. Assets owned by a husband or wife before the marriage contract will not become joint property after the marriage contract. Innate assets will remain their property. A husband cannot take his wife's possessions without his permission, and vice versa. Such conclusions can be understood from the verse of polygamy which is revealed in the context of the discussion of orphan assets. In preIslamic times, there was a tradition of marrying orphaned girls. Because of its weakness, men can control their bodies and possessions. This tradition is then reprimanded by the Qur'an:

"Give to the children who are orphaned their possessions and do not offer the bad as a good substitute. Neither do you eat their property (by combining it) into your property. That is a big sin. If you are worried about not being able to do justice in (care) of orphans, then marry only women (others) who fit your part, two, three or four "(QS. An Nisa ': 2-3).

An important message from this verse is the advice to marry only other women, and not the orphan. This is to keep from eating orphaned possessions before marriage, 
which has become a habit at that time. ${ }^{4}$ Even though this verse is devoted to the assets of orphans, it can be concluded that there is no mixing of assets with the marriage contract. The verse clearly shows that the assets of the orphan who was brought into the marriage remain his property and her husband is not allowed to take him/her.

There is no mixing of wealth because this marriage according to Arabic figh - continues. Assets obtained as a result of the husband's work, for example, will remain his property. On the other hand, the property obtained by the wife also remains her property. From this thought, in figh, there is no shared property in marriage, just the respective assets. As a consequence, the husband cannot take his wife's property without her permission, and vice versa.

This separation of property in marriage is quite clear because it is based on several propositions, both from the riwayah and from the Qur'an. In some narrations which are said to be based on the Prophet, for example there is a hadith which means that "any woman who takes her husband's property without his permission, the sin is the same as 70,000 thieves". ${ }^{5}$ As the obligation of a wife in this case is, the wife is obliged to maintain the mandate when the husband is not at home, maintain herself and protect the assets of her husband. ${ }^{6}$

Conversely, a husband may not take back gifts to his wife. This is clearly expressed by several verses of the Qur'an. For example, "it is not lawful for you (husbands) to take back what you have given them" (Surat al-Baqarah:

${ }^{4}$ Tantawi Jauhari, Al Jawabir, Juz 2, (Mesir : Musthafa al Baby al Halaby wa Auladihi, 1350H), pp. 10

${ }^{5}$ Syaikh Nawawi Al Bantani, Syarkh Uqud al Lujjain, (Surabaya : Dar al Ihya' al Kutub, tt), pp. 10

${ }^{6}$ DR. Wahbah Al Zuhaili, Al Fiqh al Islami wa Adillatubu, Juz 3, (Dimsiq : Dar al Fikr, 1409H/1989M), pp.337. 
229). In another verse it is stated: "And do not make them sad because they want to take back some of what you have given to them, except if they do a real heinous act" (QS. AnNisa ‘: 19).

In the first verse, the prohibition is in the context of ihsan divorce (well). That is, if a husband wants to bounce his wife, then he cannot take things that have been given first when he is still good. Meanwhile, the second verse tells about the context of good relationship between husband and wife (mu'asyarah bil ma'ruf). That is, a husband may not make excuses to be able to pick up items that have been given first. Whereas what is meant by giving (maa ataitumuu hunna) according to the mufassir is a general gift, either in the form of dowry or gifts that are not mandatory. It is even recommended for husbands to provide some kind of severance pay in addition to their rights which the Qur'an calls mut'ah. ${ }^{7}$ From some of the above arguments it can be understood that what the husband has given to his wife is her property, and therefore the husband must not take it back.

The provision of fiqh regarding the absence of a mixture of property due to marriage, one side is the same as the provisions of Nusantara Fiqh and Indonesian marriage law, but it is different on the other side. Indonesian marriage law also recognizes that there is no mixing of property to assets acquired before marriage or assets obtained through inheritance or gifts (Article 36 [2] UU-1/1974 and Article 85$87 \mathrm{KHI}$ ). Such assets belong to each husband and wife. But the assets obtained during marriage will be mixed together. While Arab figh argues, that the occurrence of a mixture of treasures does not continue.

${ }^{7}$ QS. Al Ahzab : 33; See Wahbah al Zuhaili, Tafsir al Munir, Juz 2, (Bairut : Dar al Fikr al Mu'ashir, tt), pp. 335; Compare with Al Jashshash, Abkam al Qur'an, Juz 1, (Bairut: Dar al Fikr lit Thiba'ah, 1414H/1993M), pp. 533 


\section{b. Mahar Ownership}

Mahar or dowry according to its function has several names, such as shadaq (giving as proof of the truth of love), faridhah (compulsory giving), ajr (wages or compensation), and 'ala'iq (as evidence of a husband and wife relationship). Mahar as a form of giving a bride to his future wife has taken place long before Islam came. In the Jahiliyah era, dowry was given to the guardian of the girl, and therefore the girl received nothing from her marriage. ${ }^{8}$ Such a tradition is then rectified by Islam which still recognizes the dowry in marriage but becomes the full right of the girl who is married and not given to the guardian. This is clearly expressed by the Qur'an, "Give a dowry to women (whom you marry) as a compulsory gift" (Q.S An Nisa ': 4).

The meaning of the verse is giving the dowry to the wives, not the guardians, as a mandatory gift. This mandatory provision means not as a purchase price or as compensation. Because the obligatory is Shari'a, it cannot be canceled by anyone other than by the Shari'ah itself. In this case, it includes the prohibition of marriage agreement without dowry. In other words, the obligation to give dowry is an obligation demanded by religion, such as the obligation to offer prayers, hajj, etc. which cannot be changed with humanity's agreement. This is a principle difference between the contract of sale and marriage contract. Buying and selling is an agreement between humans (muamalah), while the marriage contract other than containing elements of muamalah also has a stronger content of worship.

This command to give dowry to a woman can be understood as ownership. The verse can be interpreted, "give the dowry to the woman you marry, and do not give to them

${ }^{8}$ Murtadha Muththahari, Nizamu Huquq al Mar'ah fil Islam, (Teheran : Sa'ihar, 1405H/1985M), pp. 174; See Sayyid Sabiq, Fiqh as Sunnah, Juz 7, pp. 52 
other than". ${ }^{9}$ So from this verse, it can be understood that the dowry is the property of the wife and cannot be contested by anyone, including the guardian. As a legitimate property, the wife is free to do tasarruf, such as selling, renting or transferring to anyone she likes, as long as it does not violate the provisions of shara'. Another argument that confirms that the dowry belongs to the wife is also indicated by several verses. One of them is, "And if you want to replace your wife with another wife, while you have given one of them many possessions, then do not take back from him even in the slightest. Will you take it back by accusing lies and with real lies? (Surah An Nisa': 30). Prohibition of taking back dowry is also indicated by verse An Nisa: 21.

Mahar as the wife's property is required to have clear boundaries; both referred to in the marriage contract (mahar musamma) and not mentioned (mahar mitsi). For example, 100 grams of gold, a type A housing unit, and so on. The jurists or Fuqaha also agreed although the dowry may be owed (not paid in cash at the time of the contract). But the grace period for repayment must be determined and must be paid off after intercourse. ${ }^{10}$ This provision is actually not based on a strong argument, but generally fuqaha view it in analogy: that the dowry is not different from the price in buying and selling. In this case the dowry is a price or a change from the pleasure that has been given by the wife. If a divorce occurs before intercourse, then it must be paid half of the amount determined. This is based on the verse Al Baqarah: 238.

A wife as a dowry owner can make her husband free from the obligation to pay dowry, in part or in whole. But it must be the willingness of the wife and not because of the husband's tricks. In addition, dowry can also be lost because

\footnotetext{
${ }^{9}$ Murtadla Muththahari, pp. 172

${ }^{10}$ Ibnu Rusyd, Bidayatul Mujtabid, Jld. II, pp. 394
} 
of the divorce before intercourse that came from the wife. For example, the wife is an apostate, or asks for fasakh because her husband is poor, or her husband is disabled, or his wife is disabled and her husband asks for fasakh. This is the same as buying and selling. If a seller does not give the goods, then the buyer is also not obliged to pay.

In practice, this dowry varies greatly in form, level and method of payment, according to the prevailing tradition. Dowry is often more of a symbolic. The important is not the economic value or the size of the small, or expensive cheap, but its distinctive value. For example, dowry with a manuscript of the Qur'an and a set of prayer tools, as many Muslims do in Indonesia. Although dowry does not have a high economic value that can be used as a wife's property, but usually also followed by other gifts that have high economic value, such as jewelry, clothes, house, money, and so on. Giving or gifts (in Javanese term: Tukon) associated with the implementation of marriage also belong to the wife completely.

These are some dowry provisions, which are essentially the obligatory gifts from the husband to his wife according to his ability and become the legitimate property of the wife.

\section{c. Livelihood Ownership}

One of the husband's material obligations is to provide all the necessities of wife's life. This is based on strong arguments and has become the ijma' of the Muslims. The problem in this discussion is: is the provision of income an ownership or only benefit? If it is ownership, then clothing and shelter as a living are the property of the wife and are controlled completely and forever, even though the marriage ties have broken up. But if only benefits, such as clothes and houses must be left and belong to her husband when the marriage breaks up, except for the assets that have been 
awarded. In this case, the wife only receives the right of benefit as long as the marriage is still intact. In other words, if marriage breaks, who should leave the house and its contents, husband or wife? This issue is important because it relates to the right to control family assets.

Regarding this livelihood, Figh does not provide concrete solutions even though this income gets a fairly large portion of the discussion in all the books of figh. Therefore, the principles of this livelihood in terms of ownership theory will be analyzed here.

The wife's livelihood that must be fulfilled by the husband include; food (tha'am), clothing (kiswab), place/ shelter (maskan), maid (if the wife is from those who are accustomed to using helpers), cleaning equipment, household equipment, and medical expenses. Tha'am livelihood and its equipment must be given by the husband in sufficient and appropriate levels according to local customs. According to some fuqaba, the level of sufficiency is measured according to the circumstances and needs of the wife. This is based on the Hadith of the Prophet; "Khudli maa yakfiki wa waladaki bil ma'ruf" (take [the wealth of your husband] what is sufficient for you and your children in a good way). According to the author, the more appropriate opinion is that the level of adequacy is measured according to the ability of the husband and not by the willingness or needs of the wife. Because this is more rational, it is also supported by the arguments that are stronger from the Qur'an (see QS. At Thalaq: 7) and some narrations from the Prophet. For example, the words of the Prophet: Give food to them (your wives) as you eat, give their clothes like your clothes, and do not beat them and speak ill of them". This food can be delivered daily, monthly or annually according to the ability of the husband. ${ }^{11}$

${ }^{11}$ Wahbah al Zuhaili, Al Fiqh al Islami..., Juz 7, pp. 802 
Ulama also agreed that the husband in accordance with his ability is obliged to provide a living in the form of clothing to his wife according to the habit. According to Malikiyah and Hanabilah scholars, it is at least once a year at the beginning of the year. Whereas according to Shafi'iyyah and Hanafiyah, it is every semester (6 months). ${ }^{12}$

Like food and clothing, the husband is also obliged to provide a place to live to his wife according to his ability. This house must also include the bedroom, kitchen, bathroom and facilities that support the creation of a good husband and wife atmosphere (mu'asyarah bil ma'ruf). It includes providing household servants, because actually jobs such as cooking, washing, taking care of the house and so on are not included in the wife's obligations, and therefore must be paid. ${ }^{13}$

According to Shafi'i, among these types of material livelihood, istiblaki (disposable) items, such as food and drink, are ownership. Whereas items that are isti'mali (not used up), such as clothes, jewelry and shelter, are used as long as the marriage and not ownership. According to figh, it can be understood that the livelihood is in the form of isti'mali objects. A wife only gets the right of benefit. Unless the husband explicitly presents, or items that are specifically for women, such as jewelry, beauty equipment, etc., belong to the wife. Even so, livelihood still has economic value and is one of the reasons for ownership as stipulated by the Shara.

The details of the livelihoods as illustrated by the book of fiqh are merely to fulfill basic needs with examples according to the development of human needs when the books of fiqh are written. When it is viewed from the present size, human needs have undergone far-reaching changes, such as transportation needs (cars), communication (telephone),

${ }^{12}$ Ibid., pp. 803

${ }^{13}$ Ibid., pp. 805; See, Ibnu Rusyd, Juz 2, pp. 463 
entertainment equipment, sports needs, recreation and modern-day needs that have never been described by the book of figh. So the size of the living should also be adjusted to the time development.

Livelihood as a wife's right and as a way to have the property is proven when the husband is in a difficult situation and cannot provide a living. According to Jumbur fuqaha, this living obligation is a must and considered a legal debt that must be paid when the husband is able to give it. Even according to Madzab Hanafi, judges may sell the assets forcibly if husband is disobedient and does not want to pay a living. And if his assets are deliberately hidden, he must be detained (imprisoned) until he wants to pay. Furthermore, when a husband is in a difficult situation and does not provide a living, the wife can ask for a fasakh (marriage cancellation) to the judge. From these provisions, it can be concluded that livelihood is one way of transferring property from the husband to the wife, as long as the wife still fulfills the conditions for earning a living. ${ }^{14}$

\section{d. The Income of Woman Who Work}

So far, the books of figh do not have a picture of a woman working outside the home. This is because women are in full support of their husbands and are not allowed to go anywhere, including to mosques for worshipers without their husband's permission. If she must leave home, then she must be accompanied by a mabram or with a group of other women in safe conditions. ${ }^{15}$ This provision was influenced by the environment and the times when the laws of figh were

${ }^{14}$ According to Jumhur, the criteria of the wife earning a living from the husband are due to a legal marriage, the wife surrenders herself completely and can be enjoyed by her husband, and must stay in the house that her husband provides. See, Sayyid Sabiq, Juz 7, pp. 76

${ }^{15}$ Sa'di Abu Habieb, Al Maushu'ah fil Figh al Islami, Terj. KH. Sahal Mahfudz, “Ensiklopedi Ijma”, (Jakarta : Pustaka Fiedaus, 1987), pp. 663 
formulated, which indeed did not provide a peaceful place for women outside the home. But what needs to be remembered in this working woman's problem is that basically the life of a wife is borne by men. So, even if she works or is a rich woman, she still cannot take his husband's job in paying for his family's living.

The discussion of women working outside the home in several books of figh is only related to the discussion of the wives of the wife who is nusyuz. If a wife works outside the home, such as being a doctor, employee, teacher, or other professions, and the husband permits, then the husband is obliged to continue to provide a living. But if the husband does not allow it and the wife continues to work, then the obligation of living is lost, because in this case the wife is considered nusyuz. If this working wife has been required when the marriage contract, for example a woman wants to be married as long as she is allowed to continue working, then there are several opinions. According to Hanafiyah, conditions like this are fasid and useless, but the contract is still valid. According to Malikiyah, such conditions are unlawful and must not be fulfilled. Whereas according to Hanabilah, the requirement is valid, and the husband must not forbid his wife to continue working. ${ }^{16}$ Fuqaha also makes a classification of the work of a wife as job that can reduce and cannot reduce the rights of the husband. The first type of work is not allowed and the second one is allowed, including works related to the implementation of kifayah obligations, such as studying.

The problem now is, if working outside the house has become a habit, as happened in modern times today, how is the law and whose the income, she or his husband guarantees himself? In the author's opinion, the arguments that prohibit

\footnotetext{
${ }^{16}$ Wahbah al Zuhaili, Juz 7, pp. 793
} 
a woman from leaving the house, including work, need to be reviewed because women work actually have existed since the time of the Prophet, and even long before. Khadijah herself as the wife of the Prophet was a successful merchant, and she could sustain the Prophet's preaching. Likewise Aisha, had not only gone out of the house, but she had been a Jamal warlord, and no other friend had criticized her. Perhaps the prohibition of women out of the house as described by Arabic figh is more of an influence on Arab and world culture at that time which was indeed very patrilineal, and not from the teachings of Islam itself.

Nowadays, women as wives work outside the home not only as a symptom or a new trend, but it has become a common sight. And this is not felt as reducing the rights of the husband - as feared by fiqh -, even perceived as good to support the family economy. If what is feared is that the wife who works will open up the possibility of damage to the marital relationship, because with her independence in the economic field, for example, being no longer dependent on her husband and disrespectful, the truth of this hypothesis also needs to be proven by careful research. And if what is concerned is about her security - it is not to be disturbed by other men, for example - then the present condition is far different from the medieval era, where women are generally ignorant and weak.

So there is actually no argument or strong reason to prohibit women from working outside the home, as long as the work does not reduce and does not hinder good relations in the family (mu'asyarah bil ma'ruf). The work must be lawful or halal, not in conflict with her female nature and must be carried out by considering the ethics outlined by Islam, such as keeping the awrah and not exceeding the boundaries of the struggle. The wages or income from her work will belong 
to her, as the husband's income which is not given to his wife as a living also belongs to him.

\section{e. Breastfeeding and Parenting Salary}

According to fiqh, the duty of a wife seems to be nothing more than just sleeping with her husband. Cooking, washing the husband's clothes and so on are not the duty of the wife, but the wife may do it as a good service or a sadaqah to her husband. ${ }^{17}$ Breastfeeding and parenting are still disputed by the fuqaha, whether it is the obligation of the wife or not. Syafi'i, Hambali and Imamiyah Madzhab argued that women who care for their children are entitled to a salary, whether they are the biological mother or someone else. The salary is taken from the child's property, but if it does not exist, it becomes the duty of his father or the person who is obliged to provide. ${ }^{18}$ According to Imam Malik, in breastfeeding, there is a distinction between ordinary women who are low in their standard of living and high-class women. For ordinary women, they are obliged to breastfeed their children, while for high-class women, it is not mandatory, unless the baby only wants from the breast. ${ }^{19}$ According to Hanafi, caregivers are obliged to get salary if there is no longer a marriage relationship with their father and do not earn a living anymore. Salary is taken from the assets of the child, if they are not there; they are taken from the person responsible for their livelihood. ${ }^{20}$

These differences of opinion occur because each departs from a different argument. Syafi'i and his followers depart from the verse: And if you want your child to be

${ }^{17}$ Sa'di Abu Habieb, pp. 662

${ }^{18}$ Abdurrahman al Juzairi, Al Figh 'ala Mmmadzabib al Arba'ah, Juz 4, (Bairut : Dar al Fikr lit Thiba’ah, n.d), pp. 124, Compare with; Muhammad Jawab Mughniyah, Fiqh Lima Madz̧hab, (Jakarta : Basrie Press, 1414H/1994M), ppl. 418

${ }^{19}$ Ibnu Rusyd, Juz 3, pp. 465

${ }^{20}$ Muhammad Jawad Mughniyah, pp. 419 
overtaken by someone else, then there is no sin if you pay and you think it is appropriate"(Al-Baqarah: 233). This verse can be understood that a child belongs to his father, because this khithab is directed at the husband/father. Based on the understanding of this verse, it can also be understood that caring for a child is not an obligation of his wife (his mother). Therefore, she can ask for his husband's salary, such as when someone else sucks him. Moreover, the breastfeeding is essentially a feeding or a living and not a care that becomes the duty of the father.

Whereas Hanafi and his supporters departed from the argument of the verse: "If they (the wives who have been subjected to them) are pregnant, then give them their livelihood until they give birth. If they suck (your children), then give them their reward" (QS. At Thalaq: 2). According to this verse, the salary is only for wives who has been divorced, and not for those who are still in marriage and still earn a living.

According to the author, the last opinion that is followed by the majority of these scholars is more appropriate. It is odd if breastfeeding and caring for a child is not as a duty of a wife. Because of along the children's growth and development, the role of a mother is needed. Even a child must be psychologically closer to his mother than to his father. This is why the hadith of the Prophet honors a mother three times than the father.

Apart from these opinion differences, whether childcare and parenting are the duty of the father or mother. But at least from these verses, it can be concluded that the nursing and care by figh is considered to have economic value for the wife, unless the marriage has broken up. 


\section{f. Ownership of Mut'ah dan Iwadl}

Mut'ah is the gift of a kind of severance to the wife who is divorced to make her happy, according to the husband's ability. Iwadl is a kind of change from the wife to her husband as a ransom to release her. This term in figh is called kbulu'. The recommendation to provide this living is based on several verses of the Qur'an. Among them; “To divorced-women (let it be given by her husband), mut'ah according to the Ma'ruf is as an obligation for those who are devoted" "(Surat al-Baqarah: 243). ${ }^{21} \mathrm{D}$ Explicitly, this verse is concluded by scholars that giving mut'ah is obligatory, or at least the law of sunnah, as a series of the ihsan or ma'ruf talak process which can be in the form of goods, money or whatever according to the husband's abilities and prevailing habits.

If mut'ah is a gift from the husband to his wife who is divorced, then on the contrary if the one who wants divorce comes from his wife, the same gift is called iwadl. The basis of iwadl's permissibility is the verse, "And if you are worried that the two cannot do Allah's laws, then there is no sin for both of them for the payment given by the wife to redeem herself" (Al-Baqarah: 229). And the argument from the Prophet's hadith, "accept the garden and divorce it once". ${ }^{22}$ These arguments explain that a husband may take what was ever given to his wife as fida 'or ransom of divorce for him, when the wife is no longer suitable with her husband. The return of iwadl can be in the form of dowry or other assets that have been given, but must not exceed the gift. In addition, it is required that the talak initiative must really come from the wife, so that the return is based on voluntary.

${ }^{21}$ Pay attention to the other verses, QS. Al Baqarah : 236, Al Ahzab : 49, etc.

${ }^{22}$ Hadits Tsabil bin Qais, HR. Buchari, An Nasai, from Ibnu Abbas, See Wahbah al Zuhaili, Tafsir al Munir, Juz 1, pp. 242-44, Ibnu al Arabi, Abkam al Qur'an, (Bairut : Dar al Ilmiah, n.d.), pp. 264-5, Ash Shabuni, Tafsir ayat al Abkam, (Cairo : Dar al Fikr, n.d.), pp. 338 
From the above discussion about property related to marriage in the context of ownership, it can be concluded that although figh does not recognize the existence of a mixture of ownership in marriage or joint property (according to the fiqh of Nusantara marriage), but actually fiqh provides sufficient posts a lot for a wife to own her husband's possessions. Ownership posts are through dowry, livelihoods, salary for nursing and nurturing, mutahah, income earned by herself, and gifts of husbands who do not belong to these categories, such as gifts or grants. These posts must be taken into account when the marriage breaks, either because of divorce or because of death. If there is a death of the husband, for example, then the assets belonging to the wife must be calculated and distinguished in person with the tirkab assets to be shared. Thus, the tirkah understanding that will be inherited is the assets of the dead after deducting the costs of tajhiz (the management of the corpse), repayment of debts, execution of wills, and property of the widow or widower. They also must consider the living and dowry debts if they have not been paid.

\section{Position and Distribution of Marriage Assets in Nusantara Fiqh}

The above has been mentioned that what is meant by Nusantara Figh is figh which has been formulated in such a way by Indonesian jurists or fuqaba, whether it is in the form of legislation or in the form of religious organizations fatwas. Nusantara Figh which regulates the position of marital property contained in Presidential Instruction Number 1 of 1990 concerning Compilation of Islamic Law. The Compilation of Islamic Law regulated in detail about the position of assets in marriage, the types, ownership and expenditure, settlement of disputes, and distribution if marriage breaks. 


\section{a. Position of Marriage Assets}

Assets in marriage are regulated in Chapter XIII (Articles 85 to 97). KHI regulates, in addition to the existence of joint assets in the marriage, it does not rule out the possibility of property of each husband or wife (article 85). Nevertheless KHI also acknowledges: (1) basically, there is no mixing between husband's property and wife's property due to marriage; (2) the wife's property remains the wife's right and is fully controlled by her, as well as the husband's property remains the husband's right and is fully controlled by him (article 86).

Furthermore, in Article 87, it is explained: (1) the inherited assets of each husband and wife and the assets obtained respectively as an inheritance result or inheritance are under their respective control, as long as the parties do not determine otherwise in the marriage agreement. (2) Husbands and wives have the full right to do legal actions on their assets in the form of grants, gifts, sodaqah or others. The husband and wife are responsible for safeguarding both the joint assets and their assets (articles 89-90).

Joint assets (1) can be tangible or intangible objects. (2) Joint assets that are tangible can include immovable objects, movable objects and securities. (3) Joint assets that are intangible can be in the form of rights or obligations. (4) Joint assets can be used as collateral by one of the parties upon the approval of another party (article 91).

Expenditures on joint assets are regulated as follows: Husbands or wives without the consent of other parties are not allowed to sell or move joint property (Article 92). Article 93 further states: (1) Accountability for the debt of the husband or wife is charged to their property. (2) Accountability for debts carried out for the benefit of the 
family, shall be borne by joint assets. (3) If the joint property is insufficient, it is charged to the husband's assets. (4) If the husband's property does not exist or is sufficiently charged to the wife's property.

If polygamous marriages occur, so there is no mixing of joint property with second, third, and fourth wives, then it is regulated: (1) Joint assets from a marriage of a husband who has more than one wife, it is separated and independent. (2) Ownership of joint assets from a marriage of a husband who has more than one wife as referred to in paragraph (1), is calculated at the time of the second, third or fourth marriage contract (article 94).

If there is a dispute, whether concerning the type or part of each husband and wife, then Article 88 confirms: If there is a dispute between husband and wife regarding joint property, the settlement of the dispute is submitted to the Religious Court. (1) By not reducing the provisions of Article 24 paragraph (2) letter c of Government Regulation No.9 of 1975 and Article 136 place collateral seizure on joint assets without a divorce request if one of them carries out an act that is detrimental to and endangers joint assets such as gambling, drunk, wasteful, and so on. (2) During the period of confiscation, the sale of joint property for family needs can be confirmed with the permission of the Religious Court (article 95).

\section{b. Distribution of Marriage Assets}

The significance of the stipulation of joint assets in marriage is in its control and distribution. Mastery and utilization in marriage is still ongoing. While the sharing of shared assets must be done when there is a change in family structure, either because marriage breaks or polygamy occurs. 
Distribution of joint assets in broken marriage, either due to death of a husband or wife, or divorce, is regulated as follows: (1) In divorce, half of the joint assets becomes the right of a spouse who lives longer. (2). The development of joint assets for a husband or wife whose wife or husband is lost must be suspended until there is an absolute certainty of death or legal death on the basis of the decision of the Religious Court (article 96). Article 97 further stipulates that each widow or widower has the right to the second half of the joint property as long as it is not determined otherwise in the marriage agreement.

In the books of Arabic fiqh that do not know common asset, there is no description of the control and distribution of marital asset. According to fiqh, there is no mixing asset in marriage. There is just personal asset and controlled by each. The wife must not spend her husband's asset without permission, and vice versa.

Regarding the division of marriage assets, fiqh only implies that it was done when the marriage broke because one of the parties died, namely the distribution by inheritance. Even so, it is not determined definitively that the division should be carried out, for example, how many months or years after the death of muwarris. Whereas when marriage breaks due to divorce, figh does not regulate the distribution of marriage assets.

If the teachings of figh are carried out consistently, there should not only be three things - such as tajhir, repayment of debts and wills - that are considered before the inheritance is distributed. But rights must also be taken into account for surviving couples. For example, if a husband passed away before the inheritance is divided, the rights of his wife must be calculated before it is deducted for the three things, such as the unpaid dowry, the livelihoods owed, and the special gift 
given by her husband. Likewise as a result of the principle of the existence of joint property, the inheritance must be divided into two, half for the surviving spouse and the other half for inheritance. With a concept like this, the acquisition of a surviving spouse is $1 / 2$ of the joint assets plus a portion of the inheritance.

Calculation and distribution of marriage assets should also be done when polygamy or divorce occurs. When polygamy occurs, it means that a new family has been formed with second, third or fourth wives. To avoid the mixing of assets, the marriage assets must be taken into account every time a new marriage occurs. Thus, in this polygamous marriage, a number of joint assets will be formed. For example, joint asset with first wife, joint asset with first and second wife, and so on. So that the second wife cannot participate in possessing the assets acquired during the first marriage. Likewise, third wives, for example, cannot participate in possessing assets acquired during the first and second marriages.

Marriage assets must also be taken into account and divided when divorce occurs. Because divorce has the same effect as death, the marriage breaks. The difference is, when death occurs, the inheritance is shared for all heirs. Whereas when a divorce occurs, property is only shared with the former husband and wife, and children are still the responsibility of both parents. The reason for the need for this division is to avoid mixing assets.

Distribution of marital property when death, divorce or polygamy occur should be carried out as soon as possible. In the distribution due to death (inheritance), the sequence is after completing the management of the corpse, repayment of the debts of the dead and the execution of the will in a proper time according to custom. In the case of division due 
to divorce, it is concurrent with the decision to divorce by the court, or the longest time is after the $i d d a b$ period that the husband does not have the right to reconcile. In the case of distribution due to polygamy, it should be done before the second, third, or fourth marriage contract.

The hastening of the distribution of marital assets is to avoid the mixing of improper property, as well as to preserve the rights of each, not to take away rights in void, as prohibited by the Qur'an.. ${ }^{23}$ This is because the property is not something that is constant (steady), but always changes, both intentional changes (due to tasarruf), and unintentional changes (due to disasters or changes in values). As a result of these changes, there are positive and negative effects. The positive effect is the increase of the value. And the negative is that it can be reduced or exhausted altogether. Therefore, the division must be implemented immediately before the marital assets change.

\section{Istinbath Method of Nusantara Fiqh}

In the previous discussion, it is concluded that in the books of Arabic fiqh, there is no $\mathrm{n}$ term of joint assets in marriage, as recognized by the Indonesian Islamic Fiqh. It departs from a different view of the position of husband and wife in the family. Fiqh holds that the husband has a marriage so he has a higher position, especially in bearing the family's livelihood. Whereas Nusantara Fiqh views that husband and wife are like one body in having a marriage, so that they have balanced right and position, including in having a marriage property.

Persoalannya adalah, bagaimana status hukum harta bersama itu menurut Islam?. Yang dimaksudkan hukum di sini adalah boleh atau tidaknya serta jalan metodologinya.

\footnotetext{
${ }^{23}$ Lihat QS. An Nisa' :1; Al Baqarah : 188
} 
Jika boleh misalnya, apakah secara otomatis sebagai akibat dari akad nikah yang sah, ataukah diperlukan perjanjian baru di luar akad nikah?. Masalah-masalah inilah yang akan dibicarakan dalam sub ini.

The problem is what the legal status of the joint property according to Islam is. What is meant by law here is whether it is permissible or not and its methodology. If possible, for example, is it automatically the result of a legal marriage contract, or is it necessary to have a new agreement outside the marriage contract? These problems will be discussed in this point. Facing the law of joint property that has no explicit argument yet, Indonesian scholars and observers of figh generally conclude that the law is changed, and apparently no one has the opposite opinion. Thus, we can say that the legal ability of joint property in marriage has become ijma', at least for the Indonesian territory. The method of thinking (istinbath) used has conclusions that there are at least two methods, that generally view that the common property is in principle Syirkah Abdan and has become custom or tradition. ${ }^{24}$

\section{a. Qiyas Method}

Syirkah is a form of cooperation agreement (partnership) to benefit from property that is permissible in Islam, and can even reach the law of sunnah (recommended). There is no explanation or reason which was sufficient for the problem why the permissibility of the joint property is based on syirkah. Does the marriage contract automatically mean syirkah? so that the assets acquired during marriage also become joint property; or Must there be separate Syirkah contract between husband and wife outside the marriage

${ }^{24}$ Ismail Muhammad Syah, Pencaharian Bersama Suami Istri di Aceh Ditinjau dari Sudut UUP 1974 dan Hukum Islam, Disertasi, 1984, pp. 295; See Suyuti Talib, Hukum Keluarga Indonesia, (Jakarta : UI Press, 1986), pp. 79-85 
contract? For the first possibility, the pattern used is qiyas. For the second, it is a new contract.

In the opinion of the writer, it is inappropriate to explain the marriage contract with the Syirkah contract. Because qiyas is as a way to expose and explain the law for problems that have not yet been determined by the text as defined by Ushuliyyin requires complicated requirements. ${ }^{25}$

Knowing this strict qiyas pattern, it seems difficult to judge the marriage contract and the syirkah contract in the context of joint assets because both contracts have different main objectives. The purpose of the marriage contract is the halal relationship. Furthermore, the Syirkah contract is a collaboration to gain property. Thus, the qiyas requirement cannot be fulfilled because there is no similarity between illat. Both contracts are even different in other aspects, and therefore Syara 'also regulates it with different provisions.

Syirkah is indeed regulated in all the books of muamalah fiqh. But in the discussion, it never mentioned anything about the assets in marriage, especially about the marriage contract and the husband's relationship including syirkah. So concluding the permissibility of joint assets in the marriage with the qiyas argument to syirkah abdan is not appropriate. If the ownership of the joint asset is considered shirkah abdan, then it must be in a marriage agreement or there must be separate contract between husband and wife.

\section{b. 'Urf and Maslahah Method}

According to the writer's opinion, this special method for explaining the law of joint asset is more appropriate with the urf approach and maslahah mursalah. Because by deemed

${ }^{25}$ See Perhatikan qiyas requirement in various kitab Ushul Fiqh, some of them are; Wahbah al Zuhaili, Ushul Fiqh al Islami, Juz 3, (Bairut : Dar al Fikr, 1986) pp. 601; Syaifuddin al Amidi, Al Ibkam fi Ushul al Abkam, (Bairut : Dar al Kutub al Ilmiah, 1983), pp. 170 
to be urf or maslahah, the assets acquired during marriage automatically become joint asset. And this is more practical, because there is no need for active legal remedies, such as making marriage agreements or separate contracts.

Urf means good (ma'ruf). Whereas, according to the ulama' ushul, urf is: "the majority of a society's habit, whether in the form of words or deeds". ${ }^{26}$ In the view of syara', sometimes it is valid and sometimes it is fasid. It is sabih if the habit does not conflict with nash and maslabat. It is said to be fasid if the habit is contrary to the shara's argument and the basic principles that exist in the shara'.

The ulema of Ushul agreed that only valid urf can be used as a legal argument. The possibility to judge with urf is based on the general principles of Sharia. The verses of the Qur'an itself, for example, confirm the habits found in the midst of society. From these general principles of Shariah, a number of rules of figh relating to urf are formulated. Among them are: "Al 'adat mubakekamah" (tradition/habits can become law). Another rule is: "Al Tsabitu bil "urfi ka al tsabiti binnash" (What is specified using urf is the same as the one specified with nash).

The ushul experts agreed that laws based on urf could change in accordance with changes in society in certain times, places and circumstances. ${ }^{27}$

From the urf concept, it is not an exaggeration if the practice of joint property has become a common practice among the people of Indonesia. In custom/tradition laws that are applied in several regions in Indonesia, there are personal assets of husband and wife, joint or common assets

${ }^{26}$ Musthafa Ahmad Zarqa', Al Fiqh al Islami fi Tsaubibi al Jadid, Juz 2, (Bairut : Dar al Fikr, 1976), pp. 840

${ }^{27}$ Jalaluddin al Suyuthi, Asybah wa Nadzair, (Semarang: Thoha Putra, n.d.), pp. 122 
with various names according to their respective regional languages. Personal property, namely property obtained from inheritance, for example, it is called as harta gawan in Java, pusaka in Minangkabau, Sisila in Sulawesi, and so on. In Ambon, this kind of property is in the form of land that comes from clearing forests or buying. In Minahasa, it is known as a barang kelakaran. Such personal assets are usually not shared by individuals. ${ }^{28}$

Like personal property, joint assets also have several terms in accordance with their respective regions. it is called gono gini in Java, hareuta sihareukat in Aceh, and so on. The inheritance in the context of this joint property is personal property plus half of the joint assets. In Aceh - according to Ismuha's study in 1984 - the joint property was divided into $2 / 3$ for husband and $1 / 3$ for wife. ${ }^{29}$ In Java, the division of shared property is known as sepikul segendongan; sepikul (two parts) for a husband and segendongan (one part) for a wife. ${ }^{30}$ Tetapi pembagian harta bersama dengan model 2:1 ini -yang barangkali sebagai pengaruh dari hukum Iiiislam-mulai bergeser menuju keseimbangan 1:1. But this division of property using 2: 1 model - which might be the influence of Islamic law - began to shift towards 1: 1 balance. This is due to the advancement of women, in addition to the growing influence of Indonesian marital law which adheres to the husband and wife balance system.

Thus the legal reform step adopted by the Compilation of Islamic Law in determining the existence of joint property is more to adopt habits that run in the community, and thus does not conflict with the principles of Islamic law. Determination of the existence of husband and wife's joint

\footnotetext{
${ }^{28}$ Ismail Muhammad Syah, pp. 320

${ }^{29}$ Ismail Muhammad Syah, pp. 320

${ }^{30}$ Fathurrahman, Ilmu Waris, (Bandung : PT. Al Ma'arif, 1981) pp. 39-40
} 
assets can also be approached by the method of maslabah mursalab/istishlah. It establishes the law based on benefit, because there is no comment from Nash juzi (concrete Nash) or ijma'. According to Al Ghazali, the benefit is to take manfaat/benefits/advantages and reject mafsadat/ disadvantages (danger) in order to maintain the objectives of the Sharia. ${ }^{31}$ Even though there is no comment from Nash about the legality or joint property, but it can strengthen the marital relationship and can support a harmonious relationship between husband and wife, as instructed by the Qur'an with the term mu'asyarah bil ma'ruf.

Contract of marriage as said by the Qur'an itself is mistaqan ghalizhan (a strong agreement), ${ }^{32}$ and not an ordinary contract such as buying and selling, or other muamalab contracts, which can be canceled at any time. Therefore, keeping the marriage is a necessity, and vice versa, everything that can threaten the integrity of the marriage is something that must be avoided.

In a husband and wife relationship, the husband is still considered to have a big role. Although the books of figh seem reluctant to align their position in domestic life, the spirit of the Qur'an is not the same. The Qur'an views that the position of husband and wife is balanced. It can be understood by zhahir nash: "For men is part of what they are trying, and for women there is a part of what they are trying" (Surah An Nisa ': 32). This balanced position is felt to be more beneficial because a husband and wife will also be responsible for the integrity, permanence and success of a marriage, than the marriage is only owned by one party. Husbands and wives in marriage should be like one body as

31 Al Ghazali, Al Mustashfa fi Ilmi al Ushul, Juz 1, (Bairut : Dar al Kutub al Ilmiyah, 1983), pp. 286

${ }^{32}$ QS. An Nisa' : 21 
indicated by the verse: "They are the clothes for you, and you also become clothes for them" (Surat al-Baqarah: 187). Thus, the success of the husband is the happiness of the wife, and on the contrary, the failure is sadness. Such an atmosphere will be difficult to create if the property produced or got during the marriage is only controlled by the husband. The wife must get permission from the husband if she wants to use it, as taught by the books of figh.

From the above discussion about the law of joint property, it can be concluded that the establishment of joint property against property acquired during marriage, in addition to personal property, - as adopted by Indonesian marriage law - is not contrary to Islamic law. The formation can be active and passive. It can be actively agreed upon in the marriage agreement or a separate contract is made between the husband and wife in the form of syirkah abdan. Passively (automatically), it is based on urf and maslahab/usefulness consideration.

\section{Conclusion}

The books of Arabic Fiqh do not recognize the existence of a mixture of assets or property in marriage or what is called by Nusantara figh of marriage as joint property. But actually figh provides enough posts for a wife to have her own property as a result of marriage. Ownership posts are through dowry, livelihoods, wages for childbirth and nurturing, food, income earned by herself, and gifts of the husband that do not include these categories, such as gifts or grants. These wife ownership posts must be taken into account when marriage breaks, either because of divorce or because of death. If the husband passed away, for example, then the assets belonging to the wife must be calculated and distinguished in person with the tirkah assets to be shared. 
Thus, the tirkab understanding that will be inherited is the assets of the dead after deducting the costs of tajhiz (caring for the dead), repayment of debts, execution of wills, and property of the widow or widower. Living and dowry debts must also be considered if they have not been paid. When a divorce occurs, it can be the husband who has to leave the house without carrying any property, because all the property has belonged to his wife with a way of life.

One of the results of ijtihad of nusantara fuqaha, either through qiyas, marriage agreements, or because of 'urf and maslahat, it is legally stipulate that the assets acquired during marriage are as joint assets of husband and wife, except for assets obtained by means of inheritance or grant that is still owned by each. Although this conclusion is explicitly not in line with the books of Arabic figh, but it does not mean that it is contradictory. On the contrary, the determination of the existence of joint property further strengthens the marital bond as mitsqan ghalidzan, and in line with the purpose of marriage, namely to realize sakinah family, mawaddah wa rabmah. 


\section{REFERENCES}

Abdurrahman al Juzairi, Al Figh 'ala Mmmadzabib al Arba'ah, Juz 4, (Bairut : Dar al Fikr lit Thiba'ah, tt).

Al Ghazali, Al Mustashfa fi Ilmi al Ushul, Juz 1, (Bairut : Dar al Kutub al Ilmiyah, 1983).

Al Jashshash, Abkam al Qur'an, Juz 1, (Bairut : Dar al Fikr lit Thiba'ah, 1414H/1993M).

Ash Shabuni, Tafsir ayat al Abkam, (Cairo : Dar al Fikr, n.d.).

Fathurrahman, Ilmu Waris, (Bandung : PT. Al Ma'arif, 1981).

Ibnu al Arabi, Abkam al Qur'an, (Bairut : Dar al Ilmiah, n.d.).

Ibnu Mas'ud Al Kasany Al Hanafi, Bada'I al Shana'iy, Juz IV, (Bairut Libanon : Dar al Kutub Al Ilmiyah, n.d.)

Ibnu Rusyd Al Quthuby, Bidayah al Mujtabid, Juz 2 (Bairut : Dar al Fikr, n.d.).

Instruction of President Nomor 11991 about Kompilasi Hukum Islam or Islamic Law Compilation (Book I).

Ismail Muhammad Syah, Pencaharian Bersama Suami Istri di Aceh Ditinjau dari Sudut UUP 1974 dan Hukum Islam, Disertasi, 1984.

Jalaluddin al Suyuthi, Asybah wa Nadzair, (Semarang : Thoha Putra, n.d.).

Muhammad Jawab Mughniyah, Fiqh Lima Madz̧hab, (Jakarta : Basrie Press, 1414H/1994M).

Murtadha Muththahari, Nizamu Huquq al Mar'ab fil Islam, (Teheran : Sa'ihar, 1405H/1985M).

Musthafa Ahmad Zarqa', Al Fiqh al Islami fi Tsaubibi al Jadid, Juz 2, (Bairut : Dar al Fikr, 1976). 
Peraturan Pemerintah Nomor 9 Tahun 1975 tentang Pelaksanaan UU Nomor 1 of 1974 Tentang Perkawinan (Government Regulation No. 91975 about the implementation of UU No. 1 of 1974 about Marriage)

Sa'di Abu Habieb, Al Maushu'ah fil Fiqh al Islami, Transl. KH. Sahal Mahfudz, "Ensiklopedi Ijma", Jakarta : Pustaka Fiedaus, 1987).

Sayyid Sabiq, Fiqh as Sunnah, Juz 7.

Suyuti Talib, Hukum Keluarga Indonesia, (Jakarta : UI Press, 1986)

Syaifuddin al Amidi, Al Ibkam fi Ushul al Abkam, (Bairut : Dar al Kutub al Ilmiah, 1983).

Syaikh Nawawi Al Bantani, Syarkh Uqud al Lujjain, (Surabaya : Dar al Ihya' al Kutub, n.d).

Tantawi Jauhari, Al Jawahir, Juz 2, (Mesir : Musthafa al Baby al Halaby wa Auladihi, 1350H)

Undang-undang Nomor 1 Tahun 1974 tentang Perkawinan (Undang-undang/Law No. 11974 about Marriage)

Wahbah Al Zuhaili, Al Fiqh al Islami wa Adillatubu, Juz 3, (Dimsiq : Dar al Fikr, 1409H/1989M).

Wahbah al Zuhaili, Tafsir al Munir, Juz 2, (Bairut: Dar al Fikr al Mu'ashir, $\mathrm{tt})$.

Wahbah al Zuhaili, Ushul Figh al Islami, Juz 3, (Bairut : Dar al Fikr, 1986).

Yusuf Mahmud Abdul Maqsud, Abkam al Syarikat fil Fiqh al Islami al Muqaran, (Al Azhar : Darut Thiba'ah al Muhammadiyah, 1980M/1400H). 